\title{
Estimating the Monetary Policy Interest-rate-to-performance Sensitivity of the European Banking Sector at the Zero Lower Bound
}

\author{
Hayo, Bernd; Henseler, Kai; Rapp, Marc Steffen
}

Document Version

Accepted author manuscript

Published in:

Finance Research Letters

DOI:

10.1016/j.frl.2018.12.019

Publication date:

2019

\section{License}

CC BY-NC-ND

Citation for published version (APA):

Hayo, B., Henseler, K., \& Rapp, M. S. (2019). Estimating the Monetary Policy Interest-rate-to-performance Sensitivity of the European Banking Sector at the Zero Lower Bound. Finance Research Letters, 31, 471-475. https://doi.org/10.1016/j.frl.2018.12.019

Link to publication in CBS Research Portal

\section{General rights}

Copyright and moral rights for the publications made accessible in the public portal are retained by the authors and/or other copyright owners and it is a condition of accessing publications that users recognise and abide by the legal requirements associated with these rights.

\section{Take down policy}

If you believe that this document breaches copyright please contact us (research.lib@cbs.dk) providing details, and we will remove access to the work immediately and investigate your claim.

Download date: 26. Apr. 2023

$$
\text { EQUIS }
$$

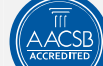




\title{
Estimating the Monetary Policy Interest-rate-to- performance Sensitivity of the European Banking Sector at the Zero Lower Bound
}

\author{
Bernd Hayo, Kai Henseler, and Marc Steffen Rapp
}

Journal article (Accepted manuscript*)

\section{Please cite this article as:}

Hayo, B., Henseler, K., \& Rapp, M. S. (2019). Estimating the Monetary Policy Interest-rate-to-performance Sensitivity of the European Banking Sector at the Zero Lower Bound. Finance Research Letters, 31, 471-475. https://doi.org/10.1016/j.frl.2018.12.019

DOI: https://doi.org/10.1016/.ffrl.2018.12.019

* This version of the article has been accepted for publication and undergone full peer review but has not been through the copyediting, typesetting, pagination and proofreading process, which may lead to differences between this version and the publisher's final version AKA Version of Record.

Uploaded to CBS Research Portal: August २०२०

(C) २018. This manuscript version is made available under the CC-BY-NC-ND 4.0 license http://creativecommons.org/licenses/by-nc-nd/4.0/ 


\title{
Estimating the monetary policy interest-rate-to-performance sensitivity of the European banking sector at the zero lower bound
}

\author{
Bernd Hayo ${ }^{\mathrm{a}} \quad$ Kai Henseler ${ }^{\mathrm{b}} \quad$ Marc Steffen Rapp ${ }^{\mathrm{b}, \mathrm{c}, \#}$
}

\section{Abstract:}

Using an event-study design, we investigate monetary policy interest-rate-to-performance sensitivity of the European banking sector over the 07/2012-06/2017 period when interest rates were (close to) zero. We apply the Wordscores approach to introductory statements of ECB's Governing Council press conferences to estimate a 'shadow prime rate'. Based on short-run intraday event windows, we find shadow prime rate changes positively affect changes in the EURO-STOXX-Banks Future. Our findings add to the recent evidence documenting that banks benefit from increasing interest rate levels in a low-interest-rate environment.

JEL-Classification: E43, E52, E58, G14, G21

Keywords: ECB, central bank communication, banking sector, interest rate sensitivity, textual analysis, Wordscores

Highlights:

- We study EURO-STOXX-Banks Future during ECB's Governing Council press conferences

- We find trading in EURO-STOXX-Banks Future to increase after press conferences start

- We estimate a 'shadow prime rate' from press conference transcripts using Wordscores

- EURO-STOXX-Banks Future reacts positively to changes in our 'shadow prime rate'

- Banks' net worth benefits from increasing rates in a low-interest-rate environment

MACIE, School of Business and Economics, Macroeconomic Research Group, Philipps-Universität Marburg, Germany.

b School of Business and Economics, Accounting and Finance Area, Philipps-Universität Marburg, Germany.

Center for Corporate Governance, Copenhagen Business School, Denmark.

* Corresponding author. Philipps-Universität Marburg, School of Business \& Economics, Am Plan 1, 35032 Marburg (Germany). E-mail: msr@m-s-rapp.de.

Declarations of interest: none (applies to all authors). 


\section{Introduction}

What is the monetary policy interest-rate-to-performance sensitivity of the banking sector? Following Flannery and James (1984), most empirical literature supports classic textbook arguments, which cumulate in the hypothesis that banks-being financial intermediaries engaged in maturity transformation-will suffer from increasing interest rate levels. ${ }^{1}$ However, does this hypothesis hold in a low-interestrate environment?

Recently, a number of central banks-including the FED, the ECB, the BOJ, and the BoE-reduced their interest rates towards the zero lower bound. In a low-interestrate environment, resulting in diminishing net interest rate margins (e.g., Claessens, Coleman, \& Donnelly, 2018), banks might have limited ability (and willingness) to pass through interest rates. Thus, when interest rates are low, empirical evidence by Claessens et al. (2018) and Ampudia and van den Heuvel (2018) points towards a reversal of the classic Flannery and James (1984) interest-rate-to-performance sensitivity for the banking sector.

Reversal of the banking sector's interest-rate-to-performance sensitivity in a lowinterest-rate environment could have important consequences, in that it might signal a nonlinear monetary policy transmission mechanism. Brunnermeier and Koby (2018) combine the standard maturity mismatch channel with the net interest margin argument and develop a theoretical model in which, below a certain threshold, the intended effect of an accommodative monetary policy becomes reversed.

Our contribution is to link the performance of the European banking sector to the ECB's monetary policy stance over the 07/2012-06/2017 period when interest rates were (close to) zero. The zero lower bound restricts conventional interest rate policies, but does not restrict ECB's verbal communication. We analyse transcripts of

\footnotetext{
${ }^{1}$ See the discussion in English et al. (2018).
} 
introductory statements of ECB's press conferences following Governing Council (GC) meetings ${ }^{2}$ using textual analysis. Drawing on Laver et al. (2003), Jansen and de Haan (2010), and Bennani (2018), we apply the Wordscores approach to these introductory statements to estimate a 'shadow prime rate' (SPR). Employing an event-study design using high-frequency intraday data, we then link changes in the SPR to performance of the EURO-STOXX-Banks Future.

We find that the EURO-STOXX-Banks Future reacts positively to increases in the SPR. In our baseline specification, a 50 basis points hike in the SPR results in about a 1 per cent increase of the EURO-STOXX-Banks Future. These results are robust to modifications of the event window, controls for contemporaneous announcements of asset purchase programmes (APP), and the inclusion or exclusion of further control variables.

Our findings add to the evidence documenting that banks benefit from increasing interest rate levels in a low-interest-rate environment (e.g., Ampudia \& van den Heuvel, 2018; Claessens et al., 2018) and suggest a nonlinear policy transmission mechanism (e.g., Brunnermeier \& Koby, 2018). However, while Ampudia and van den Heuvel (2018) and Claessens et al. (2018) link banking-sector stock market reactions to market-based interest-rate reactions, we establish a direct causal relationship between a communication-based SPR and European banks' net worth. Ampudia and van den Heuvel (2018) mainly focus on the 13:45CET press statements; we focus on verbal guidance during press conferences starting at 14:30CET.

2 Usually, the Governing Council meets every two weeks (see www.ecb.europa.eu/press/ govcdec/html/index.en.html, accessed 21-07-2018). General timing: 12:00CET start of the meeting, 13:45CET press statement, 14:30CET start of the press conference. 


\section{Data and methodology}

Our sample starts 05-07-2012, when the ECB set its deposit facility rate to zero, and ends in 08-06-2017. ${ }^{3}$ It covers 50 GC press conferences for which we estimate the shadow prime rate (changes) and corresponding changes in banks' net worth.

We proceed in four steps. First, we use textual analysis-more specifically, the Wordscores approach-to extract a 'shadow prime rate' (SPR) from ECB's verbal communication during GC press conferences. Developed by Laver et al. (2003), Wordscores is a computerised textual analysis that compares word frequencies and orders texts along a predefined dimension. To ensure consistency, we restrict the analysis to 'introductory statements' prepared by the GC and presented by the ECB president.

We calibrate our model with the 1999-2006 GC press conference 'introductory statement' transcripts and corresponding changes in ECB's deposit facility rate. ${ }^{4}$ Wordscores then provides us with a measure $\phi$, ranging from -0.77 to +0.80 , suggesting an ECB monetary policy stance that-during the calibration period, when interest rates did not reach the zero lower bound-is associated with a decrease $(\phi<0) /$ no change $(\phi=0) /$ increase $(\phi>0)$ of the deposit facility rate. We use $\phi$ to construct SPR, interpreting $\phi$ as indicating a decrease/ no change/ increase in the SPR, i.e., as representing $\triangle S P R$ - the change in SPR. ${ }^{5}$

The resulting $\triangle$ SPR and its aggregation (SPR) are shown in Figure 1. SPR declines until 2014, bounces back in 2015, and then hovers around zero for the rest of the sample period.

3 The sample period matches the low-interest-rate environment period studied in Ampudia and van den Heuvel (2018).

4 For example, the ECB lowered its deposit facility rate by 0.50 basis points on $05-06-2003$. Accordingly, the press conference transcript is coded -0.50 .

5 A detailed description is available from the authors. 
Figure 1: $(\Delta)$ Shadow prime rate during 07/2012-06/2017

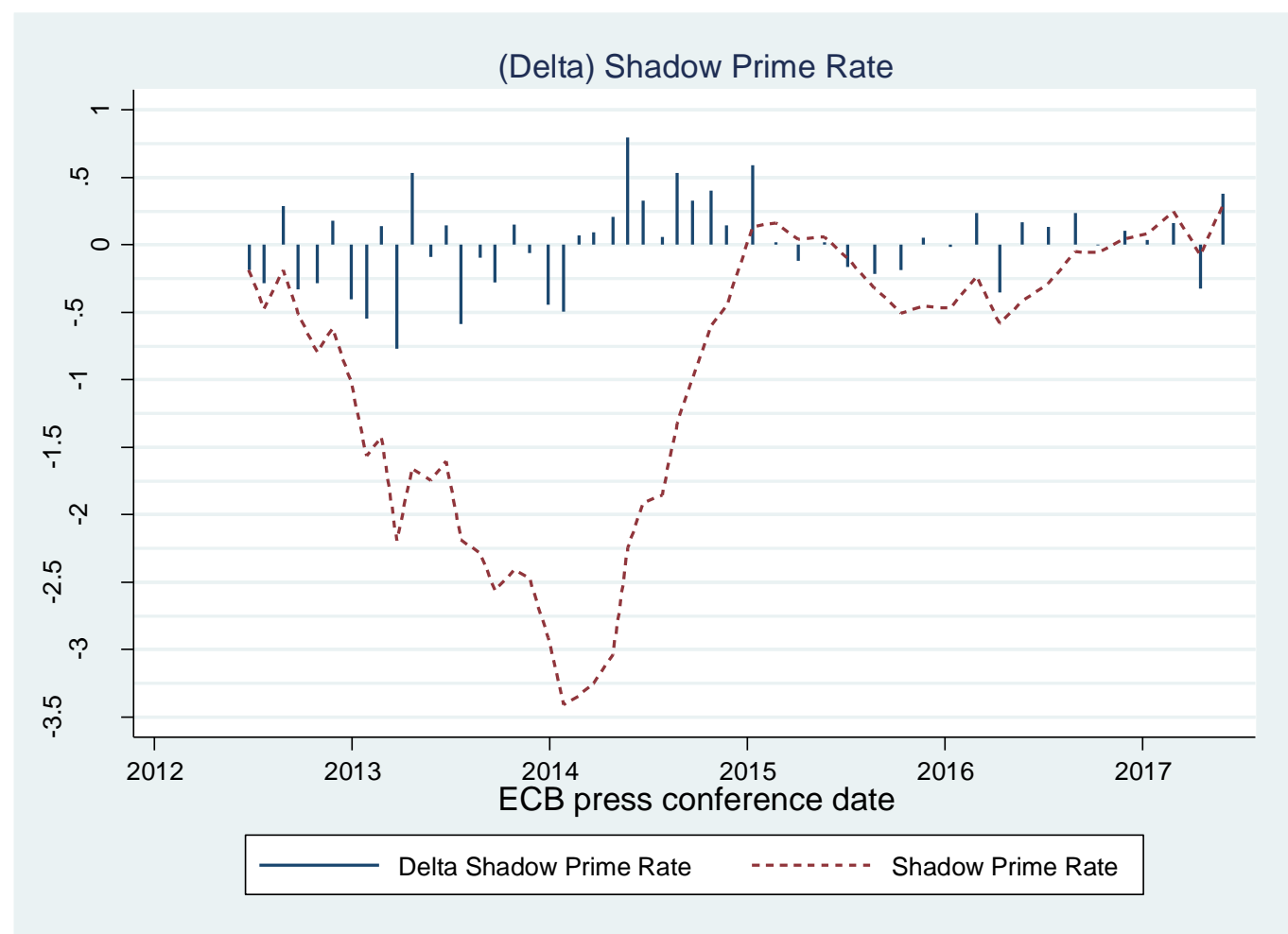

Notes: $(\Delta)$ Shadow prime rate calculated for the 50 GC press conferences in our sample period.

Second, we inspect trading volumes in the EURO-STOXX-Banks Future around GC press conferences. As Figure 2 suggests, the conference introductory statements are followed closely by market participants. On GC meeting days, excess trading volume of the EURO-STOXX-Banks Future increases substantially at the start of the introductory statement at 14:30CET, a much more pronounced increase than occurs after the prime-rate decision is announced at 13:45CET. 
Figure 2: Excess trading in EURO-STOXX-Banks Future on GC meeting days

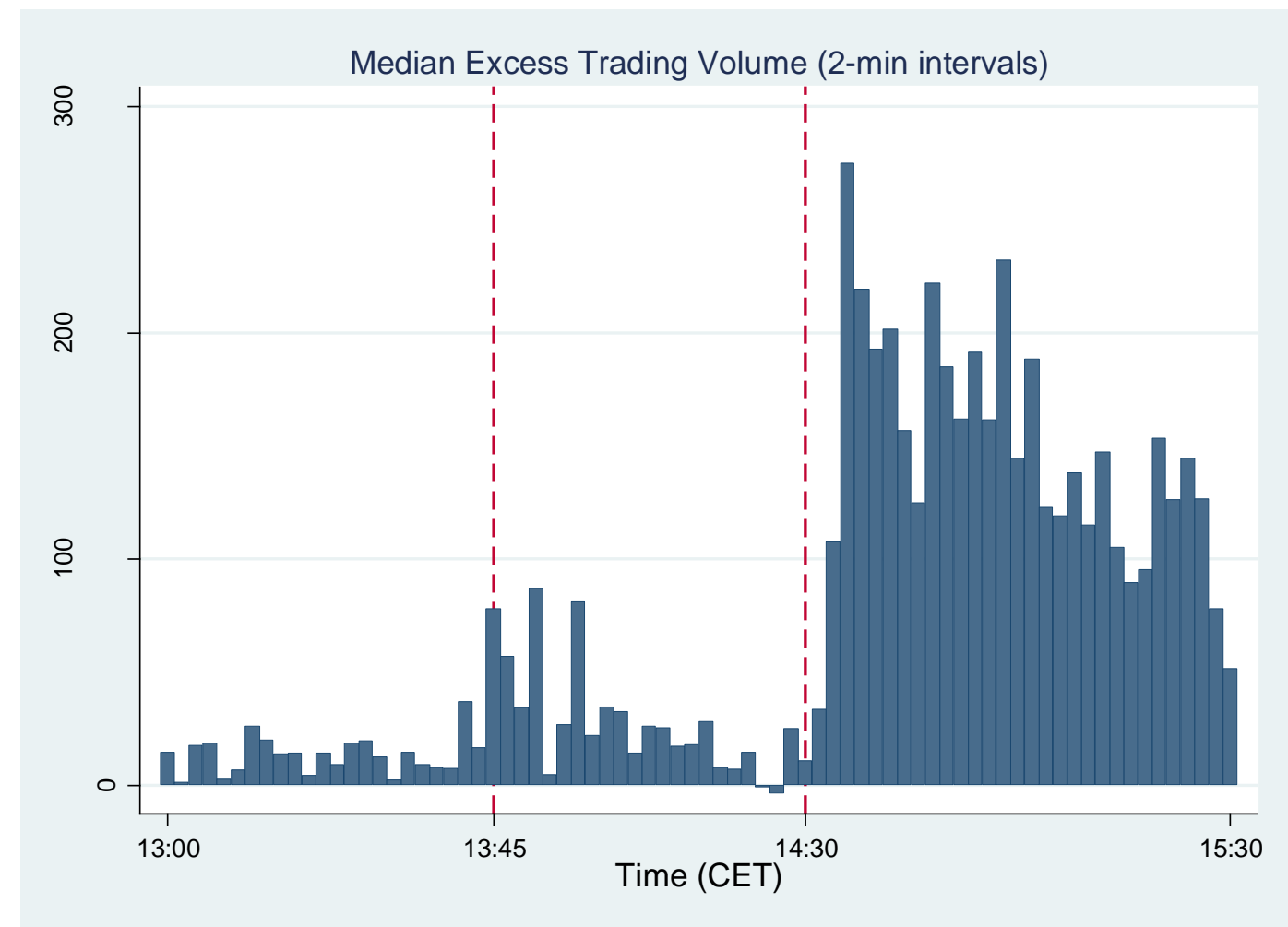

Notes: Median excess trading volume for 2-minute intervals of the EURO-STOXX-Banks Future across 50 GC meeting days during $07 / 2012-6 / 2017$. Excess trading volume: actual EUREX trading volume less median EUREX trading volume on non-meeting days.

Third, we use price data of the EURO-STOXX-Banks Future (Product-ISIN: DE0005705651) as an indicator of banks' net worth and calculate its log-returns, which we denote $R_{t ; w}$ ( $t$ : event date; $w$ : event window). Given that the average length of the introductory speeches is around 13 minutes, we use a 15 -minute (25minute) event window, comparing prices at 14:44CET (14:54CET) to those at 14:29CET, just before press conference commences.

Fourth, we link changes in the SPR to changes in banks' net worth by regressing $R_{t ; w}$ on $\Delta$ SPR and a set of control variables. Table 1 contains details about the empirical approach. 
Table 1: Regression model and variables

\begin{tabular}{|c|c|}
\hline Model & \\
\hline \multicolumn{2}{|c|}{$\mathrm{R}_{\mathrm{t} ; \mathrm{w}}=\alpha+\beta \cdot \Delta \mathrm{SPR}+\gamma \cdot$ Controls $+\delta \cdot$ Year dummies $+\varepsilon$} \\
\hline \multicolumn{2}{|l|}{ Returns } \\
\hline $\mathrm{R}_{\mathrm{t} ; \mathrm{w}}$ & $\begin{array}{l}\text { In(Price }[14: 29+w] / \text { Price }[14: 29]) \cdot 100 \\
\text {-Price: EURO-STOXX-Banks Future } \\
\text {-Windows }(w): 15-\mathrm{min} / 25-\text { min } \\
\text {-Events }(\mathrm{t}): \text { GC press conferences }\end{array}$ \\
\hline \multicolumn{2}{|l|}{ Coefficients } \\
\hline$\beta, \gamma$ & Coefficients (reported) \\
\hline$\delta$ & Coefficients (non-reported) \\
\hline$\varepsilon$ & Error term \\
\hline \multicolumn{2}{|l|}{$\triangle S P R$} \\
\hline$\triangle \mathrm{SPR}$ & $\begin{array}{l}\text { Calculated using Wordscores, calibrated based on introductory statement } \\
\text { transcripts of GC press conferences in 1999-2006 and corresponding } \\
\text { changes in the deposit facility rate }\end{array}$ \\
\hline \multicolumn{2}{|l|}{ Controls } \\
\hline APP-Announcement-Dummy & $\begin{array}{l}\text { Announcement of asset purchase programme initiation or further pro- } \\
\text { gramme details of a previously announced programme (yes/no) }\end{array}$ \\
\hline Overlap-Dummy & Unconventional monetary policy contemporaneously announced (yes/no) \\
\hline $\begin{array}{l}\text { Rate-Change-Dummy } \\
\text { Bond-Return }\end{array}$ & $\begin{array}{l}\text { Deposit facility rate change announced } 13: 45 \text { CET (yes/no) } \\
\text { In(Price }[14: 29] / \text { Price }[13: 44] \text { ), based on EURO-BUND Future }\end{array}$ \\
\hline
\end{tabular}

\section{Empirical results}

Table 2 reports our regression results. Our baseline model links $\triangle$ SPR to EUROSTOXX-Banks Future returns measured over a 15-minute event window. Additional models use a longer event window or control for APP announcements. We start with specifications containing further control variables, but employ a consistent testingdown process to derive efficiently estimated reduced specifications (see Hendry, 1993).

In our baseline model, EURO-STOXX-Banks Future returns are positively and significantly affected by $\triangle$ SPR. For the general (reduced) model, the coefficient of 2.1 (1.4) indicates a 50 basis points increase in $\triangle S P R$, resulting in an EURO-STOXXBanks Future return of $+1.1(+0.7)$ per cent. Thus, our monetary policy interest- 
rate-to-performance sensitivity is lower than the market interest-rate-to-performance sensitivity reported by Ampudia and van den Heuvel (2018), assuming a corresponding return of +4.0 per cent. ${ }^{6}$

Table 2: Explaining EURO-STOXX-Banks Future returns using OLS regressions

\begin{tabular}{|c|c|c|c|c|c|c|}
\hline \multirow{2}{*}{$\begin{array}{l}\text { Variables } \\
\Delta \text { SPR }\end{array}$} & \multicolumn{2}{|c|}{$\begin{array}{c}\text { Baseline-regression } \\
\text { 15-min returns }\end{array}$} & \multicolumn{2}{|c|}{$\begin{array}{c}\text { Extended event-window } \\
\text { 25-min returns }\end{array}$} & \multicolumn{2}{|c|}{$\begin{array}{c}\text { Control for APP-effects } \\
15 \text {-min returns }\end{array}$} \\
\hline & $\begin{array}{l}2.10 * * \\
(2.22)\end{array}$ & $\begin{array}{l}1.39 * * \\
(2.54)\end{array}$ & $\begin{array}{l}2.34^{* *} \\
(2.26)\end{array}$ & $\begin{array}{l}1.21 * \\
(1.92)\end{array}$ & $\begin{array}{l}2.01 * * \\
(2.31)\end{array}$ & $\begin{array}{l}1.64^{* *} \\
(2.20)\end{array}$ \\
\hline APP-Announceme.-Dummy & & & & & $\begin{array}{l}-0.45 \\
(-0.72)\end{array}$ & $\begin{array}{l}-0.81 \\
(-0.88)\end{array}$ \\
\hline Overlap-Dummy & $\begin{array}{c}-0.75 \\
(-0.83)\end{array}$ & & $\begin{array}{l}-1.43 \\
(-1.65)\end{array}$ & & $\begin{array}{c}-0.46 \\
(-0.67)\end{array}$ & \\
\hline Rate-Change-Dummy & $\begin{array}{l}-0.68 \\
(-0.79)\end{array}$ & & $\begin{array}{l}-0.84 \\
(-0.81)\end{array}$ & & $\begin{array}{l}-0.65 \\
(-0.76)\end{array}$ & \\
\hline Bond-Return & $\begin{array}{c}1.91 \\
(1.23)\end{array}$ & & $\begin{array}{c}1.58 \\
(0.83)\end{array}$ & & $\begin{array}{c}2.00 \\
(1.22)\end{array}$ & \\
\hline Observations & 50 & 50 & 50 & 50 & 50 & 50 \\
\hline Year-Dummies & Yes & No & Yes & No & Yes & No \\
\hline $\mathrm{R}^{2}$ & 0.36 & 0.10 & 0.33 & 0.06 & 0.37 & 0.14 \\
\hline Testing-down restriction & $\begin{array}{c}F(8,40)= \\
0.71\end{array}$ & & $\begin{array}{c}F(8,40)= \\
0.93\end{array}$ & & $\begin{array}{c}F(8,39)= \\
0.71\end{array}$ & \\
\hline
\end{tabular}

Notes: OLS regression with robust standard errors; t-statistics in parentheses.

$*: p<0.10 ; * *: p<0.05 ; * * *: p<0.01$.

Our baseline results are robust to model variations (extended event window and additional APP control) and unreported tests employing alternative monetary policy interest-rate measures or control variables as well as an extended sample period. ${ }^{7}$

\section{Conclusion}

Interest rates approaching the zero lower bound has alerted economists and policymakers to a potential reversal of the banking sector's interest-rate-to-performance sensitivity. We employ an intraday event-study design and estimate the monetary policy interest-rate-to-performance sensitivity of the European banking

6 However, Ampudia and van den Heuvel (2018) obtain their results during press statements (13:45CET), not during press conferences (14:30CET).

7 All unreported tests are available from the authors. 
sector over the $07 / 2012-06 / 2017$ period when interest rates were (close to) zero, based on a carefully constructed 'shadow prime rate'. Our results show that the banking sector's net worth, measured by the EURO-STOXX-Banks Future, reacts positively to changes in the shadow prime rate.

Our findings add to the evidence documenting that banks benefit from increasing interest rate levels in a low-interest-rate environment, though the effect size appears lower than previously reported. This supports the hypothesis that textbook predictions of banks suffering from higher interest rates may not hold at the zero lower bound and that, in practice, nonlinearities may play an important role in monetary policy transmission. 


\section{Acknowledgments}

Funding: The academic work of Kai Henseler is financially supported by a scholarship from the Konrad-Adenauer Foundation. 


\section{References}

Ampudia, M., \& van den Heuvel, S. (2018). Monetary Policy and Bank Equity Values in a Time of Low Interest Rates (SSRN Working-Paper).

Bennani, H. (2018). The Art of Central Bank's Forward Guidance at the Zero Lower Bound. Revue Économique, 69(1), 111-137.

Brunnermeier, M.K., \& Koby, Y. (2018). The Reversal Interest Rate (Working-Paper).

Claessens, S., Coleman, N., \& Donnelly, M. (2018). 'Low-for-Long' Interest Rates and Banks' Interest Margins and Profitability: Cross-Country Evidence. Journal of Financial Intermediation, 35(Part-A), 1-16.

English, W.B., van den Heuvel, S.J., \& Zakrajsek, E. (2018). Interest Rate Risk and Bank Equity Valuations. Journal of Monetary Economics, 98, 80-97.

Flannery, M.J., \& James, C.M. (1984). The Effect of Interest Rate Changes on the Common Stock Returns of Financial Institutions. Journal of Finance, 39(4), 1141-1153.

Hendry, D.F. (1993). Econometrics: Alchemy or Science? Oxford: Blackwell Publishing Inc.

Jansen, D.-J., \& de Haan, J. (2010). An Assessment of the Consistency of ECB Communication Using Wordscores (DNB Working-Paper).

Laver, M., Benoit, K., \& Garry, J. (2003). Extracting Policy Positions from Political Texts Using Words as Data. American Political Science Review, 97(2), 311331. 


\section{Appendix (not for publication)}

This appendix to "Estimating the monetary policy interest-rate-to-performance sensitivity of the European banking sector at the zero lower bound" is intended to provide (A) technical details on the Wordscores Approach, (B) details on the EUROSTOXX-Banks Future, (C) full empirical results, and (D) additional robustness tests.

\section{(A) Technical details on the Wordscores Approach}

We apply the Wordscores approach as introduced by Laver et al. (2003). Wordscores is a computerised textual analysis that compares word frequencies and orders texts along a predefined dimension. This method was developed for applications in political sciences research, but has lately been used in the field of economics (e.g., Bennani, 2018; Jansen \& de Haan, 2010). Its main advantages are that it (i) requires no distributional assumptions, (ii) minimises subjective judgments, and (iii) has been proven in numerous applications. Moreover, it can be directly run in Stata using publicly available Do-Files and instructions. ${ }^{8}$ However, to ensure transparency, it is important to provide details about the data and the parameters used in our analysis.

For using Wordscores to estimate a 'shadow prime rate' (SPR) for the introductory statements of the 50 Governing Council (GC) press conferences in our 07/2012$06 / 2017$ sample ('virgin texts'), it is key to carefully select 'reference texts'. We decided to use the preceding 1999-2006 GC press conference introductory statement transcripts as reference texts. 1999 is the starting date as that is when the ECB was established and the first GC meeting took place. 2006 is the ending date

8 See https://www.tcd.ie/Political_Science/wordscores/. 
so as to avoid any overlap with press conferences during the 2008 financial crisis and changes in the press conference wording that could bias our set of references.

We calibrate those reference texts on the corresponding changes of the ECB deposit facility rate. ${ }^{9}$ For example, the ECB lowered its deposit facility rate by 0.50 basis points on 05-06-2003. Accordingly, the transcript for the corresponding GC press conference introductory statement is coded -0.50 . The reason for this calibration is that we are primarily interested in the interest rate change and not in the absolute level. During 1999-2006, 21 such adjustments of the deposit facility rate were implemented by the ECB, for 17 the corresponding GC press conference transcripts are publicly available. Those 17 transcripts with their respective change in deposit facility rate are used as references texts. A comprehensive list is provided in Table A1.

Table A1: Reference texts for SPR calculation in Wordscores

\begin{tabular}{|c|c|c|c|c|}
\hline Year & Date & $\begin{array}{c}\text { Deposit facility } \\
\text { Absolute rate }\end{array}$ & $\begin{array}{l}\text { Deposit facility } \\
\text { Change in rate }\end{array}$ & Comment \\
\hline \multirow[t]{5}{*}{2006} & 13.12 & 2.50 & 0.25 & \\
\hline & 11.10 & 2.25 & 0.25 & \\
\hline & 09.08. & 2.00 & 0.25 & \\
\hline & 15.06. & 1.75 & 0.25 & \\
\hline & 08.03. & 1.50 & 0.25 & \\
\hline 2005 & 06.12. & 1.25 & 0.25 & \\
\hline \multirow[t]{2}{*}{2003} & 06.06. & 1.00 & -0.50 & \\
\hline & 07.03. & 1.50 & -0.25 & \\
\hline 2002 & 06.12 . & 1.75 & -0.50 & \\
\hline \multirow[t]{4}{*}{2001} & 09.11 . & 2.25 & -0.50 & \\
\hline & 18.09. & 2.75 & -0.50 & excluded; no transcript \\
\hline & 31.08 . & 3.25 & -0.25 & \\
\hline & 11.05. & 3.50 & -0.25 & \\
\hline \multirow[t]{6}{*}{2000} & 06.10 & 3.75 & 0.25 & \\
\hline & 01.09. & 3.50 & 0.25 & excluded; no transcript \\
\hline & 09.06. & 3.25 & 0.50 & \\
\hline & 28.04. & 2.75 & 0.25 & excluded; no transcript \\
\hline & 17.03. & 2.50 & 0.25 & excluded; no transcript \\
\hline & 04.02 . & 2.25 & 0.25 & \\
\hline \multirow[t]{2}{*}{1999} & 05.11 . & 2.00 & 0.50 & \\
\hline & 09.04. & 1.50 & -0.50 & \\
\hline
\end{tabular}

Notes: ECB deposit facility absolute rates are retrieved from https://www.ecb.europa.eu/stats/ policy_and_exchange_rates/key_ecb_interest_rates/html/index.en.html, accessed 02-02-2018.

9 Our results remain robust when using the ECB main refinancing rate instead. 
We retrieved all 'reference texts' and 'virgin texts' as MS-Word files from the ECB homepage. ${ }^{10}$ To minimise any modification of our 'reference texts' and 'virgin texts', we limited our pre-cleaning of texts to a minimum. Therefore, we only removed punctuation and number values from our texts and transformed all texts into plain ASCII format. To account for word combinations (e.g., 'quantitative easing'), we set the phrasefreq parameter in Wordscores to 2 so as to not only consider single words (unigrams) but also word pairs (bigrams).

We also use Wordscores to estimate an alternative 'APP-Announcement' control variable, capturing the extent of asset purchase programme (APP) related communication within our sample of 50 GC press conference introductory statements. As a robustness test, we include this variable instead of the APP-Announcement-Dummy and report the results in section D of this appendix. However, we face two challenges. First, the limited calibration period: APP-related communication exists only from May 2009 onward (when the ECB began engaging in 'Quantitative Easing' and launched the 'Covered Bond Purchase Programme', the first of a series of largescale APPs). With regard to 'reference texts', we are therefore limited to the GC press conferences in $05 / 2009-12 / 2011$. The second challenge is the lack of a readily available quantitative APP proxy. We decided to manually calibrate the 'reference texts' by manually coding all GC press conference introductory statements from $05 / 2009-12 / 2011$ into five categories $(-1,-0.5,0,+0.5,+1)$ based on their APPrelated content ('monetary easing': -1 ; 'monetary tightening': +1). All introductory statements without substantial APP-related content were excluded. The remaining nine introductory statement transcripts used as 'reference texts' are listed in Table A2.

10 See https://www.ecb.europa.eu/press/pressconf, accessed: 01-02-2018. 
Table A2: Reference texts for APP-announcement calculation in Wordscores

\begin{tabular}{l|r|r|r|r} 
Year & Date & $\begin{array}{r}\text { Manual coding } \\
\text { regarding APP }\end{array}$ & $\begin{array}{r}\text { Overlap with } \\
\text { APP measure }\end{array}$ & Comment \\
\hline 2011 & 08.12. & 1.0 & no & \\
& 03.11. & -0.5 & yes & CBPP1 Details \\
2010 & 06.10. & -1.0 & yes & CBPP1 Initiation \\
& 10.06. & 1.0 & no & \\
& 06.05. & -1.0 & yes & SMP Initiation \\
& 06.08. & 1.0 & no & \\
& 02.07. & 1.0 & no & \\
& 04.06. & -0.5 & yes & CBPP1 Details \\
& 07.05. & -1.0 & yes & CBPP1 Initiation
\end{tabular}

Notes: GC press conference introductory statement transcripts for 05/2009-12/2011 manually coded into five categories $(-1,-0.5,0,+0.5,+1)$ based on APP-related content; 'monetary easing':

-1 ; 'monetary tightening': +1 .

Regarding text processing and parameter setting, we use the same standards for APP-Announcement calculation as for SPR calculation, described above.

\section{(B) Details on the EURO-STOXX-Banks Future}

Interested in measuring the stock market reaction of the Eurozone banking sector, we select the EURO-STOXX-Banks index. This index seems appropriate, as it is comprised solely of banking stocks (in total 27 components, as of 14-09-2018) within the EU-12 countries (Austria, Belgium, Finland, France, Germany, Greece, Ireland, Italy, Luxembourg, the Netherlands, Portugal, and Spain). However, due to its high liquidity, we opt for the corresponding index future: Product-ISIN: DE0005705651; Currency: EUR; Underlying instrument: EURO-STOXX Banks index (ESTX BANKS INDEX (PRICE), ISIN: EU0009658426). We retrieve all data from Portara-CQG.

\section{(C) Full empirical results}

In this section, we report the full empirical results of our analysis. Due to length restrictions, we limit the reported results in the main part of this study to our key explanatory variables and the key controls. However, to ensure reliability and be fully transparent, Table A3 reports all variables used in our regression analyses. 
Due to indications for heteroscedasticity, we conduct all regressions using robust standard errors.

Table A3: Full empirical results

\begin{tabular}{|c|c|c|c|c|c|c|}
\hline \multirow{2}{*}{$\begin{array}{l}\text { Variables } \\
\triangle \text { SPR }\end{array}$} & \multicolumn{2}{|c|}{$\begin{array}{c}\text { Baseline-regression } \\
15-\text { min returns }\end{array}$} & \multicolumn{2}{|c|}{$\begin{array}{c}\text { Extended event-window } \\
25 \text {-min returns }\end{array}$} & \multicolumn{2}{|c|}{$\begin{array}{c}\text { Control for APP-effects } \\
15 \text {-min returns }\end{array}$} \\
\hline & $\begin{array}{l}2.10 * * \\
(2.22)\end{array}$ & $\begin{array}{l}1.39 * * \\
(2.54)\end{array}$ & $\begin{array}{l}2.34 * * \\
(2.26)\end{array}$ & $\begin{array}{l}1.21^{*} \\
(1.92)\end{array}$ & $\begin{array}{l}2.01 * * \\
(2.31)\end{array}$ & $\begin{array}{r}1.64 * * \\
(2.20)\end{array}$ \\
\hline APP-Announce.-Dummy & & & & & $\begin{array}{l}-0.45 \\
(-0.72)\end{array}$ & $\begin{array}{l}-0.81 \\
(-0.88)\end{array}$ \\
\hline Overlap Dummy & $\begin{array}{l}-0.75 \\
(-0.83)\end{array}$ & & $\begin{array}{l}-1.43 \\
(-1.65)\end{array}$ & & $\begin{array}{l}-0.46 \\
(-0.67)\end{array}$ & \\
\hline Rate-Change Dummy & $\begin{array}{l}-0.68 \\
(-0.79)\end{array}$ & & $\begin{array}{l}-0.84 \\
(-0.81)\end{array}$ & & $\begin{array}{l}-0.65 \\
(-0.76)\end{array}$ & \\
\hline Bond Return & $\begin{array}{c}1.91 \\
(1.23)\end{array}$ & & $\begin{array}{c}1.58 \\
(0.83)\end{array}$ & & $\begin{array}{c}2.00 \\
(1.22)\end{array}$ & \\
\hline 2012 Dummy & $\begin{array}{l}-1.29 \\
(-1.28)\end{array}$ & & $\begin{array}{l}-1.06 \\
(-1.12)\end{array}$ & & $\begin{array}{l}-1.30 \\
(-1.28)\end{array}$ & \\
\hline 2013 Dummy & $\begin{array}{c}0.15 \\
(0.37)\end{array}$ & & $\begin{array}{c}0.02 \\
(0.04)\end{array}$ & & $\begin{array}{c}0.09 \\
(0.22)\end{array}$ & \\
\hline 2014 Dummy & $\begin{array}{l}-0.38 \\
(-0.80)\end{array}$ & & $\begin{array}{l}-0.10 \\
(-0.16)\end{array}$ & & $\begin{array}{l}-0.41 \\
(-0.83)\end{array}$ & \\
\hline 2015 Dummy & - & & - & & - & \\
\hline 2016 Dummy & $\begin{array}{c}0.42 \\
(0.58)\end{array}$ & & $\begin{array}{c}0.68 \\
(0.91)\end{array}$ & & $\begin{array}{c}0.38 \\
(0.53)\end{array}$ & \\
\hline 2017 Dummy & $\begin{array}{l}0.60 \\
(0.72)\end{array}$ & & $\begin{array}{c}1.03 \\
(1.28)\end{array}$ & & $\begin{array}{c}0.41 \\
(0.55)\end{array}$ & \\
\hline Constant & $\begin{array}{c}0.26 \\
(0.75)\end{array}$ & $\begin{array}{l}-0.20 \\
(-0.99)\end{array}$ & $\begin{array}{c}0.29 \\
(0.70)\end{array}$ & $\begin{array}{l}-0.32 \\
(-1.45)\end{array}$ & $\begin{array}{l}0.28 \\
(0.77)\end{array}$ & $\begin{array}{l}-0.04 \\
(-0.26)\end{array}$ \\
\hline Observations & 50 & 50 & 50 & 50 & 50 & 50 \\
\hline $\mathrm{R}^{2}$ & 0.36 & 0.095 & 0.33 & 0.062 & 0.37 & 0.14 \\
\hline Testing-down restriction & $\begin{array}{c}F(8,40)= \\
0.71\end{array}$ & & $\begin{array}{l}F(8,40) \\
=0.93\end{array}$ & & $\begin{array}{c}F(8,39)= \\
0.71\end{array}$ & \\
\hline
\end{tabular}

Notes: OLS regression with robust standard errors; t-statistics in parentheses. $*: p<0.10 ; * *: p<0.05 ; * * *: p<0.01$.

\section{(D) Additional robustness tests}

To ensure the robustness of our findings, we consider an extended event window as well as an additional dummy variable to control for contemporaneous announcements of asset purchase programmes (APP) in the main part of this study. However, to test for the change in interest-rate-to-performance sensitivity in the low-interestrate environment, it seems reasonable to test an extended sample period. We therefore apply our regressions to an extended sample of 92 GC press conferences cov- 
ering the period $01 / 2009-06 / 2017$. We interact $\Delta$ SPR with a dummy variable indicating whether the low-interest-rate environment is reached ( $\triangle \mathrm{SPR}$ multiplied by 1 after $05 / 07 / 2012$ and multiplied by 0 otherwise). We find positive significant coefficients after this day, but insignificant coefficients before, as shown in Table A4.

Table A4: Robustness regarding the sample period

\begin{tabular}{|c|c|c|}
\hline \multirow{2}{*}{$\begin{array}{l}\text { Variables } \\
\Delta \text { SPR } \times \text { Low-Interest-Rate Dummy [1] }\end{array}$} & \multicolumn{2}{|c|}{$\begin{array}{c}\text { Extended sample } 2009-2017 \\
15 \text {-min returns }\end{array}$} \\
\hline & $\begin{array}{l}1.66 * * \\
(2.41)\end{array}$ & $\begin{array}{l}1.39 * * \\
(2.57)\end{array}$ \\
\hline$\Delta$ SPR x Low-Interest-Rate Dummy [0] & $\begin{array}{l}0.13 \\
(0.27)\end{array}$ & $\begin{array}{l}0.10 \\
(0.29)\end{array}$ \\
\hline Overlap Dummy & $\begin{array}{l}-0.28 \\
(-0.63)\end{array}$ & \\
\hline Rate-Change Dummy & $\begin{array}{l}-0.05 \\
(-0.11)\end{array}$ & \\
\hline Bond Return & $\begin{array}{c}0.95 \\
(1.11)\end{array}$ & \\
\hline 2009 Dummy & $\begin{array}{c}0.02 \\
(0.04)\end{array}$ & \\
\hline 2010 Dummy & $\begin{array}{l}-0.11 \\
(-0.22)\end{array}$ & \\
\hline 2011 Dummy & $\begin{array}{c}0.01 \\
(0.01)\end{array}$ & \\
\hline 2012 Dummy & $\begin{array}{l}-1.20^{*} \\
(-1.81)\end{array}$ & \\
\hline 2013 Dummy & $\begin{array}{c}0.21 \\
(0.51)\end{array}$ & \\
\hline 2014 Dummy & $\begin{array}{l}-0.40 \\
(-0.82)\end{array}$ & \\
\hline 2015 Dummy & - & \\
\hline 2016 Dummy & $\begin{array}{c}0.12 \\
(0.23)\end{array}$ & \\
\hline 2017 Dummy & $\begin{array}{c}0.35 \\
(0.64)\end{array}$ & \\
\hline Constant & $\begin{array}{c}0.12 \\
(0.29)\end{array}$ & $\begin{array}{l}-0.19 \\
(-1.29)\end{array}$ \\
\hline Observations & 92 & 92 \\
\hline $\mathrm{R}^{2}$ & 0.25 & 0.07 \\
\hline Testing-down restriction & $\begin{array}{c}F(11,78)= \\
0.72\end{array}$ & \\
\hline
\end{tabular}

Notes: OLS regression with robust standard errors;

t-statistics in parentheses. ${ }^{*} \mathrm{p}<0.10 ; * * \mathrm{p}<0.05 ; * * * \mathrm{p}<0.01$. 
Another reasonable area for deeper analysis is the definition of our explanatory variable. Thus, we test three alternative $\triangle$ SPR definitions, which we call 'Change in $\triangle S P R$ ' and 'Surprise $\triangle S P R$ ', with the latter separated into two specifications, which we call 'Surprise $\Delta$ SPR $[\mathrm{t}=3]$ ' and 'Surprise $\Delta \mathrm{SPR}[\mathrm{t}=4]$ '.

'Change in $\triangle S P R^{\prime}$ is calculated as $\triangle \mathrm{SPR}_{\mathrm{t} 0}-\triangle \mathrm{SPR} \mathrm{R}_{\mathrm{t}-1}$. 'Surprise- $\Delta S P R^{\prime}$ is calculated by estimating Predicted- $\triangle S P R$, as the fitted value from a Predicted- $\Delta S P R$ regression with $\triangle$ SPR measures from previous months as determinants, and then computing the difference between (observed) $\Delta$ SPR and Predicted- $\Delta S P R$.

For 'Surprise $\triangle \mathrm{SPR}[\mathrm{t}=3]^{\prime}$ ', the estimation model is:

Predicted $\Delta S P R_{t}[t=3]=\beta_{1} \cdot \Delta S P R_{t-1}+\beta_{2} \cdot \Delta S P R_{t-2}+\beta_{3} \cdot \Delta S P R_{t-3}+\varepsilon_{t}$ Surprise $\triangle S P R_{t}[t=3]=$ Observed $\Delta S P R_{t}-$ Predicted $\Delta S P R_{t}[t=3]$

For 'Surprise $\triangle \mathrm{SPR}[\mathrm{t}=4]$ ', the corresponding estimation model is:

Predicted $\Delta S P R_{t}[t=4]=\beta_{1} \cdot \Delta S P R_{t-1}+\beta_{2} \cdot \Delta S P R_{t-2}+\beta_{3} \cdot \Delta S P R_{t-3}+\beta_{4} \cdot \Delta S P R_{t-4}+\varepsilon_{t}$ Surprise $\triangle S P R_{t}[t=4]=$ Observed $\triangle S P R_{t}-$ Predicted $\Delta S P R_{t}[t=4]$

The results are reported in Table A5. For all three alternative $\Delta$ SPR definitions, we find significantly positive coefficients, supporting our baseline results. In all three cases, the level of significance for the specifications excluding control variables even increases to the 1 per cent level. 
Table A5: Robustness regarding the SPR definition

\begin{tabular}{|c|c|c|c|c|c|c|}
\hline \multirow{2}{*}{$\begin{array}{l}\text { Variables } \\
\text { Change in } \triangle \text { SPR }\end{array}$} & \multicolumn{2}{|c|}{$\begin{array}{l}\text { Change in } \triangle S P R \\
15 \text {-min returns }\end{array}$} & \multicolumn{2}{|c|}{$\begin{array}{c}\text { Surprise } \triangle S P R \text { [t=3] } \\
15 \text {-min returns }\end{array}$} & \multicolumn{2}{|c|}{$\begin{array}{c}\text { Surprise } \triangle S P R[t=4] \\
15 \text {-min returns }\end{array}$} \\
\hline & $\begin{array}{l}0.83 * * \\
(2.36)\end{array}$ & $\begin{array}{c}0.78^{* * *} \\
(3.04)\end{array}$ & & & & \\
\hline Surprise $\Delta S P R[t=3]$ & & & $\begin{array}{l}1.26 * * \\
(2.18)\end{array}$ & $\begin{array}{c}1.03 * * * \\
(2.73)\end{array}$ & & \\
\hline Surprise $\Delta S P R[t=4]$ & & & & & $\begin{array}{l}1.24 * * \\
(2.20)\end{array}$ & $\begin{array}{c}0.93 * * * \\
(2.90)\end{array}$ \\
\hline Overlap Dummy & $\begin{array}{l}-0.21 \\
(-0.29)\end{array}$ & & $\begin{array}{l}-0.26 \\
(-0.35)\end{array}$ & & $\begin{array}{l}-0.27 \\
(-0.36)\end{array}$ & \\
\hline Rate-Change Dummy & $\begin{array}{l}-0.35 \\
(-0.38)\end{array}$ & & $\begin{array}{l}-0.56 \\
(-0.61)\end{array}$ & & $\begin{array}{l}-0.58 \\
(-0.64)\end{array}$ & \\
\hline Bond Return & $\begin{array}{c}1.64 \\
(1.12)\end{array}$ & & $\begin{array}{c}1.80 \\
(1.15)\end{array}$ & & $\begin{array}{c}1.83 \\
(1.18)\end{array}$ & \\
\hline 2012 Dummy & $\begin{array}{l}-1.73 \\
(-1.48)\end{array}$ & & $\begin{array}{l}-1.77 \\
(-1.53)\end{array}$ & & $\begin{array}{l}-1.82 \\
(-1.54)\end{array}$ & \\
\hline 2013 Dummy & $\begin{array}{l}-0.098 \\
(-0.27)\end{array}$ & & $\begin{array}{c}-0.21 \\
(-0.56)\end{array}$ & & $\begin{array}{c}-0.24 \\
(-0.63)\end{array}$ & \\
\hline 2014 Dummy & $\begin{array}{l}-0.16 \\
(-0.32)\end{array}$ & & $\begin{array}{l}-0.24 \\
(-0.49)\end{array}$ & & $\begin{array}{l}-0.28 \\
(-0.57)\end{array}$ & \\
\hline 2015 Dummy & - & & - & & - & \\
\hline 2016 Dummy & $\begin{array}{c}0.14 \\
(0.21)\end{array}$ & & $\begin{array}{l}0.088 \\
(0.13)\end{array}$ & & $\begin{array}{l}0.053 \\
(0.08)\end{array}$ & \\
\hline 2017 Dummy & $\begin{array}{c}0.26 \\
(0.34)\end{array}$ & & $\begin{array}{c}0.22 \\
(0.30)\end{array}$ & & $\begin{array}{c}0.21 \\
(0.28)\end{array}$ & \\
\hline Constant & $\begin{array}{c}0.16 \\
(0.45)\end{array}$ & $\begin{array}{l}-0.19 \\
(-0.94)\end{array}$ & $\begin{array}{c}0.26 \\
(0.71)\end{array}$ & $\begin{array}{l}-0.20 \\
(-0.96)\end{array}$ & $\begin{array}{c}0.29 \\
(0.79)\end{array}$ & $\begin{array}{l}-0.20 \\
(-0.97)\end{array}$ \\
\hline Observations & 50 & 50 & 50 & 50 & 50 & 50 \\
\hline $\mathrm{R}^{2}$ & 0.30 & 0.06 & 0.32 & 0.06 & 0.31 & 0.05 \\
\hline Testing-down restriction & $\begin{array}{c}F(8,40)= \\
0.59\end{array}$ & & $\begin{array}{c}F(8,40)= \\
0.64\end{array}$ & & $\begin{array}{c}F(8,40)= \\
0.66\end{array}$ & \\
\hline
\end{tabular}

Notes: OLS regression with robust standard errors; t-statistics in parentheses.

$* \mathrm{p}<0.10 ; * * \mathrm{p}<0.05 ; * * * \mathrm{p}<0.01$.

Eventually, we also test an alternative 'APP-Announcement' control variable for contemporaneous announcements of asset purchase programmes (APP). Variable calculation follows the description provided in section $A$ of this appendix. We intend to measure APP-related content more comprehensively compared to the dummy variable used in the specifications reported in Table 2 . However, we find coefficients to be robust and to remain in similar size and level of significance, as reported in Table A6. 
Table A6: Robustness regarding the control for APP

\begin{tabular}{|c|c|c|}
\hline \multirow{2}{*}{$\begin{array}{l}\text { Variables } \\
\triangle \text { SPR }\end{array}$} & \multicolumn{2}{|c|}{$\begin{array}{c}\text { Control for APP-effects } \\
15 \text {-min returns } \\
\end{array}$} \\
\hline & $2.29 * *$ & $1.30 * *$ \\
\hline & $(2.34)$ & $(2.22)$ \\
\hline \multirow[t]{2}{*}{ APP-Announcement (Wordscores) } & $-0.49 *$ & -0.14 \\
\hline & $(-1.85)$ & $(-0.86)$ \\
\hline \multirow[t]{2}{*}{ Overlap Dummy } & -1.43 & \\
\hline & $(-1.33)$ & \\
\hline \multirow[t]{2}{*}{ Rate-Change Dummy } & -1.03 & \\
\hline & $(-1.23)$ & \\
\hline \multirow[t]{2}{*}{ Bond Return } & 1.13 & \\
\hline & $(0.79)$ & \\
\hline \multirow[t]{2}{*}{2012 Dummy } & -0.98 & \\
\hline & $(-1.04)$ & \\
\hline \multirow[t]{2}{*}{2013 Dummy } & 0.21 & \\
\hline & $(0.51)$ & \\
\hline \multirow[t]{2}{*}{2014 Dummy } & -0.19 & \\
\hline & $(-0.40)$ & \\
\hline 2015 Dummy & - & \\
\hline \multirow[t]{2}{*}{2016 Dummy } & 1.37 & \\
\hline & $(1.30)$ & \\
\hline \multirow[t]{2}{*}{2017 Dummy } & 1.46 & \\
\hline & $(1.33)$ & \\
\hline \multirow[t]{2}{*}{ Constant } & 0.27 & -0.19 \\
\hline & $(0.76)$ & $(-0.95)$ \\
\hline Observations & 50 & 50 \\
\hline $\mathrm{R}^{2}$ & 0.41 & 0.10 \\
\hline \multirow[t]{2}{*}{ Testing-down restriction } & $F(8,39)=$ & \\
\hline & 0.95 & \\
\hline
\end{tabular}

Notes: OLS regression with robust standard errors;

t-statistics in parentheses. ${ }^{*} \mathrm{p}<0.10 ; * * \mathrm{p}<0.05 ; * * * \mathrm{p}<0.01$. 


\section{References for Appendix (not for publication)}

Bennani, H. (2018). The Art of Central Bank's Forward Guidance at the Zero Lower Bound. Revue Économique, 69(1), 111-137.

Jansen, D.-J., \& de Haan, J. (2010). An Assessment of the Consistency of ECB Communication Using Wordscores (DNB Working Paper).

Laver, M., Benoit, K., \& Garry, J. (2003). Extracting Policy Positions from Political Texts Using Words as Data. American Political Science Review, 97(2), 311-331. 